\title{
Personalized immunotherapy for non-small cell lung cancer through identification of tumor-specific mutations by next generation sequencing and adoptive transfer of tumor infiltrating lymphocytes that recognize neoantigens
}

\author{
Ken-ichi Hanada ${ }^{1 *}$, Christopher Chow ${ }^{1}$, Raul Gil Hoyos ${ }^{1}$, Jared J Gartner ${ }^{2}$, Todd D Prickett ${ }^{1}$, Robert Somerville ${ }^{1}$, \\ Katherine Hogan', Paul F Robbins', Steven A Rosenberg', James C Yang ${ }^{3}$ \\ From 30th Annual Meeting and Associated Programs of the Society for Immunotherapy of Cancer (SITC \\ 2015) \\ National Harbor, MD, USA. 4-8 November 2015
}

\section{Background}

Patients with metastatic melanoma can be successfully treated with adoptive transfer of tumor infiltrating lymphocytes (TIL). In 93 patients with over 5 year follow-up, the overall response rate was $56 \%$ and $20 \%$ achieved durable complete responses persisting in excess of 7 years. However, past attempts to apply TIL therapy to other solid cancers have not been successful and low frequency of tumor-specific $\mathrm{T}$ cells in other cancers has been suspected as a reason.

Recent progress in Next Generation Sequencing technology has enabled us to analyze genetic mutations in an individual patient's tumor and identify immune cells that are reactive to these mutation-encoded neoantigens. The potential of this therapeutic approach recently was illustrated in a patient with cholangiocarcinoma who experienced major tumor regression when given such $\mathrm{T}$ cells. NSCLC is a cancer with a high number of genetic mutations and a recent report suggests that clinical response of NSCLC to anti-PD1 antibody therapy is positively associated with the number of genetic mutations.

'NCl, NIH, Bethesda, MD, USA

Full list of author information is available at the end of the article

\section{Results}

To identify neoantigen-reactive T cells from NSCLC and utilize them for adoptive therapy, we initiated clinical protocol (NCT02133196). Initial Whole Exome Sequence analysis of freshly resected metastases from four patients with NSCLC showed between 150 and 1500 non-synonymous mutations that could be confirmed by RNAseq. TIL cultures from these tumors tend to be initially dominated by $\mathrm{CD}^{-}, \mathrm{CD}^{2} 6^{+}$cells, gradually converting to $\mathrm{CD} 3$ ${ }^{+} \mathrm{CD} 4^{+}$dominant, $\mathrm{CD} 3{ }^{+} \mathrm{CD} 8^{+}$dominant, or a mixture of both at approximately 3 weeks. In all the cases, we were able to find $\mathrm{CD} 4^{+}$and/or $\mathrm{CD} 8^{+} \mathrm{T}$ cell populations that were reactive to one or more autochthonous neoantigens as confirmed by IFN- $\gamma$ ELISPOT and FACS analysis based on 4-1BB and/or OX-40 up-regulation. In multiple TIL cultures, more than $50 \%$ of the cells were reactive to a neoantigen and in one case, single mutation in NPM1 (nucleophosmin) yielded both $\mathrm{CD} 4^{+}$and $\mathrm{CD}^{+} \mathrm{T}$ cell reactivity. These $\mathrm{T}$ cells can be grown to large numbers in vitro for patient adoptive transfer and these studies are underway.

\footnotetext{
Authors' details

${ }^{1} \mathrm{NCl}, \mathrm{NIH}$, Bethesda, MD, USA. ${ }^{2}$ Surgery Branch/National Cancer Institute / National Institutes of Health, Bethesda, MD, USA. ${ }^{3}$ National Institutes of Health, Bethesda, MD, USA.
} 
doi:10.1186/2051-1426-3-S2-P20

Cite this article as: Hanada et al:. Personalized immunotherapy for nonsmall cell lung cancer through identification of tumor-specific mutations by next generation sequencing and adoptive transfer of tumor infiltrating lymphocytes that recognize neoantigens. Journal for ImmunoTherapy of Cancer 2015 3(Suppl 2):P20.

Submit your next manuscript to BioMed Central and take full advantage of:

- Convenient online submission

- Thorough peer review

- No space constraints or color figure charges

- Immediate publication on acceptance

- Inclusion in PubMed, CAS, Scopus and Google Scholar

- Research which is freely available for redistribution

Submit your manuscript at www.biomedcentral.com/submit
C Biomed Central 